e-ISSN: 2550-1313 | p-ISSN: 2087-9849

http://jurnal.fkip.unila.ac.id/index.php/jpp/

\title{
Professional Development of Teachers in Bandar Aceh, Indonesia: A Case of SMA Negeri 1 Sigli
}

\author{
Multhaza, Yusrizal, Bahrun \\ Department of Education Administration, Syiah Kuala University, Indonesia \\ *Corresponding email: $\underline{\text { multhaza@gmail.com }}$
}

Received: 27 October 2019

Accepted: 21 July 2020

Published: 25 November 2020

Abstract: Professionalism Development of Teachers in Bandar Aceh, Indonesia: A Case of SMA Negeri 1 Sigli. Objectives: This study aims to find and describe the development of teacher profesionalism in SMA Negeri 1 Sigli with regard to : (1) planning the development of teacher profesionalism, (2) implementing the development of teacher teacher professionalism and (3) constraints in developing teacher professionalism. Methods: This study uses a descriptive method with a qualitative approach. Data collection techniques are carried out through interviews, observation and documentation. The subjects in this study were school principals, teachers and school supervisors. Findings: The results of the study show that: (1) teacher development planning has been carried out well and in detail, planning is carried out by teachers, schools and educational institutions; (2) the implementation of teacher development has been carried out properly and effectively in accordance with the principles and procedures for the continuous development of teachers; (3) constraints faced in teacher development in the form of the ability to use ICT that has not been comprehensive, the time of implementation, and financing in self-development.

Keywords: Teachers professional development, qualitative approach, Indonesia.

Abstrak: Pengembangan Profesionalisme Guru di Bandar Aceh, Indonesia: Kasus SMA Negeri 1 Sigli. Tujuan: Penelitian ini bertujuan untuk menemukan dan mendeskripsikan pengembangan profesionalisme guru di SMA Negeri 1 Sigli berkenaan dengan: (1) perencanaan pengembangan profesionalisme guru, (2) penerapan pengembangan profesionalisme guru dan (3) kendala dalam pengembangan profesionalisme guru. Metode: Penelitian ini menggunakan metode deskriptif dengan pendekatan kualitatif. Teknik pengumpulan data dilakukan melalui wawancara, observasi dan dokumentasi. Subjek dalam penelitian ini adalah kepala sekolah, guru dan pengawas sekolah. Temuan: Hasil penelitian menunjukkan bahwa: (1) perencanaan pengembangan guru telah dilaksanakan dengan baik dan rinci, perencanaan dilakukan oleh guru, sekolah dan lembaga pendidikan; (2) pelaksanaan pengembangan guru telah dilaksanakan dengan baik dan efektif sesuai dengan prinsip dan prosedur pengembangan guru yang berkelanjutan; (3) kendala yang dihadapi dalam pengembangan guru berupa kemampuan pemanfaatan TIK yang belum lengkap, waktu pelaksanaan, dan pembiayaan dalam pengembangan diri.

Kata kunci: Pengembangan profesional guru, pendekatan kualitatif, Indonesia.

\section{To cite this article:}

Multhaza., Yusrizalq, \& Bahrun. (2020). Professional Development of Teachers in Bandar Aceh, Indonesia: A Case of SMA Negeri 1 Sigli. Jurnal Pendidikan Progresif, 10(3), 478-484. doi: 10.23960/ jpp.v10.i3.202009. 


\section{INTRODUCTION}

A teacher holds a strategic role especially in shaping the national character and to develop students' potential (Kelly et.al., 2019; Darmuki, 2018; Panadero, Brown, \& Strijbos, 2016). Teachers also have a very important role in determining the success of education.Professional teachers are expected to be able to produce quality graduates (Muskietaet.al., 2019; Bakar, 2018). One of the requirements for a teacher to be said professional is that the teacher has competencies or abilities that are in accordance with the standards. Competency is a set of knowledge, skills and values that are at the basis reflected in the habits of thought and action of the professionals (Kong \& Kong, 2019; LaRochelle et.al., 2019; Nickerson, Lamb, \& LaRochelle, 2017). Professional development of teachers must be recognized as a very fundamental and important thing to improve the quality of education (Blanchard, 2019; Simkin, Mozhaeva, \&Proskurin, 2019; Maba, Perdata, \& Astawa, 2017). Specifically teachers are required to provide professional services to students so that learning objectives are achieved. So that teachers who are said to be professionals are people who have special abilities and expertise in the field of teacher training so that they are able to carry out their duties and functions as teachers with maximum abilities (Liu \& Xu, 2019; Moltudal, 2019; Toom et.al., 2017).

Government policies in order to actualize the role of teachers as agents of change need to be supported by all parties. One of the formulas for maintaining teacher professionalism is through teacher performance appraisal, this assessment is needed as a requirement for upgrading and fostering career ranks and teacher positions (DeNisi \& Murphy, 2017; Mohrman \& Lawler, 2017). Teacher performance assessment is carried out through credit score assessments, which include elements of: education, learning/ guidance and specific assignments, continuous professional development and supporting teacher assignments (Stacey et. al., 2019; Hochstetler \& Orzulak, 2019; Gutiérrez, 2018). If all this time the elements of education, learning / guidance and certain tasks have become routine activities of the teacher's work, so that it does not become a complicated problem for teachers to carry out and collect credit scores, it is not the case with the development of the teaching profession which has not been a concern and has not become part of important of the teacher's activities in maintaining his professionalism.

Efforts to develop teacher professionalism need to be carried out continuously so that their knowledge, understanding and skills related to their assignments always keep abreast of developments in the world of education (Hutt, Gottlieb, \& Cohen, 2018; Siraj \& Milfayetty, 2017) Various development models have actually been put forward by many education experts that are tailored to the abilities and needs of teachers (Senaratne \& Gunarathne, 2019). Therefore, this paper discusses various types of teacher professional development that teachers can use according to their needs. The effectiveness of each model depends on the situation and conditions that surround the teacher. The teacher will give various models choices to improve their professional development. Teacher achievements in Pidie District are currently not so good when compared to a few years ago, there were many awards events for outstanding teachers, outstanding subject teachers and education personnel, which came very little from Pidie District. The low achievement of teachers in various kinds of activities at this time could be due to the less than optimal development of the teaching profession from the education units of each teacher and the local education office .

As one of the reference schools in Pidie District, SMA Negeri 1 Sigli is one of the best choice senior high school in Pidie District. Schools 
that already have a large number of students, and already have complete facilities for teaching and learning activities. Of the number of teachers who teach at the school is also sufficient for all subjects, but in fact there is currently no outstanding teacher from SMA Negeri 1 Sigli in recent years. Teachers in these schools should be peer tutors for other school teachers in the field of writing scientific papers, discussers in scientific activities and some forms of innovative work and other teacher development activities. Based on the illustration above, the researchers conducted research at SMA Negeri 1 Sigli to see how the development of teacher professionalism at SMA Negeri 1 Sigli.

\section{METHODS}

This research uses a descriptive method with a qualitative approach, which is describing and analyzing the development of teacher professionalism of teachers at SMA Negeri 1 Sigli. Through a qualitative approach, researchers can identify facts or events as variables that are affected and conduct investigations on variables that influence. This research was conducted at SMA Negeri 1 Sigli. The reason the researcher chose SMA Negeri 1 Sigli was because the school had a number of teachers, study groups and supporting infrastructure for the effective teaching and learning process . The subjects of this study were the principal, school supervisors, teachers.

\section{RESULT AND DISCUSSION}

A. Planning for Teacher Professional Development in State High School 1 Sigli

In planning a program especially in developing professionalism of teachers in SMA Negeri 1 Sigli, namely conducting an analysis of programs that have been run both in terms of training, further study, seminars, etc. and will get a design that will be implemented in the future both will continue the program have been running, replace with another program or implement a new program that is in accordance with what is needed in developing the professionalism of the teacher, budgeting funds properly in accordance with the needs submitted to the foundation that houses the 1 Public High School Sigli so that in the implementation of teacher professional development is not impressed suddenly, analyzing the needs in accordance with the development of the world of education, especially in responding to technological progress and the development of the education curriculum, the school management conducts an appropriate analysis in developing teacher professionalism. In this case the principal is obliged to plan a teacher professionalism development program referring to the evaluation of programs that have been carried out as a material consideration in planning further programs. Furthermore, the program arranged by the teacher concerned in terms of education and training outside school activities in the form of self-development through formal education in the form of continued $\mathrm{p}$ Education to pursue higher and formal education are short courses. This is in accordance with the planning function including setting organizational goals, establishing an overall strategy for achieving goals and developing a comprehensive hierarchy of plans to integrate and coordinate activities in more detail.

The target of all teacher professionalism development activities that have been prepared by schools, teachers and related education offices is to uphold a teacher's professional ability in teaching and is expected to improve student learning outcomes in order to achieve national education goals. The planned activities have been very detailed in accordance with the ongoing professional development activities that serve as benchmarks for teacher development at this time. Referring to the theory above, it is expected that school management and the education office in planning 
must be more focused on the urgency of the needs that exist in the Sigli 1 Public High School, such as the programs that will be carried out in the coming year in detail. And all programs that will be implemented are socialized in advance to the entire board of teachers and ask for consideration and input so that the planned program can run optimally. Planning the professional development of teachers in SMA 1 Sigli made by the school in this case the school management and the school heads and their deputies supervisor schools have well implemented. aking for action in achieving organizational goals with or without using available resources. Planning aspects covered; (a) what will be done, (b) who has to do it, (c) when it will be done, (d) where it will be done, (e) how to do it, and (f) what needs to be done in order to achieve its objectives optimally.

B. Implementation of Teacher Professionalism Development in SMA Negeri 1 Sigli

The implementation of teacher professionalism development activities at SMA Negeri 1 Sigli in the form of continuing professional development has been very good. Activities that have been planned by the school, education office and teachers have been running optimally, but there are some activities that cannot be carried out in accordance with the plan. Personal development activities consist of two types, namely functional training and teacher collective activities. These self-development activities are intended so that teachers are able to achieve and/or improve teacher professional competence which includes: pedagogical, personality, social, and professional competencies as mandated in Law Number 20 Year 2003 concerning the National Education System.

Functional training is a teacher's activity in attending education or training that aims to achieve the specified professional competency standards and/or improve professionalism to have competencies above the professional competency standard within a certain period of time. In this case the implementation of the development of teacher professionalism has been very good implementation, because the functional training activities are well organized by the education department as the executor of the activity. Activities that are focused in one place with very professional presenters really help the teacher in his professional development as a teacher. Teacher collective activities are teacher activities in following scientific meetings or joint activities aimed at achieving standards or above the established professional competency standards. Collective activity implementation activities are also very effective, because the organization of teacher organizations in general as well as the deliberations of subject teachers (MGMP) have been formed with all subjects in the district of Pidie. The facilitation provided by the education office in the form of place and funding is very helpful in facilitating the current collective activities of teachers.

Scientific publications are scientific papers that have been published to the community as a form of teacher's contribution to improving the quality of the learning process in schools and the development of education in general while innovative works are works that are development, modification or new discoveries as a form of teacher's contribution to improving the quality of the learning process in schools and the development of education, science / technology, and art. In this case the implementation of the rock teacher scientific publications is limited to the writing of papers in the form of research reports in the field of education in schools which are published/published at the school or district level, not yet published at the provincial or national level, the making of papers in the form of classroom action research conducted by teachers not every year and sometimes only for the needs of rank desire. In the case of innovative works that are 
still lacking in implementation, there are only a few teachers who plan this activity to be carried out with MGMP groups but there are no innovative works in the form of new discoveries that can be used in education.

Professional development is a form of continuous learning for teachers which is the main vehicle for the desired change related to student success. Continuing professional development encourages teachers to continue to maintain and improve overall competence in areas related to their work as a teacher. Thus, teachers can continue to improve and expand their knowledge and skills so as to create the quality of teachers in life. In general, it aimed to improve the quality of education services in schools / madrasas in order to improve the quality of education. Specifically the objectives of the programs are as follows: Facilitating teachers to achieve predetermined professional competency strains; Facilitating teachers to update (renew) the competencies they have now with what is required in the future relating to their profession; Motivating teachers to remain committed to carrying out their main tasks and functions as professional staff; Raising the image, dignity, dignity of the teaching profession, and increasing respect and pride for the teaching profession; Increasing more professional teachers; Give awards to professional teachers, among which are group advances; and Give high motivation to reach the rank of civil servants, namely the Main Builder.

C. Constraints in the Development of Teacher Professionalism in SMA Negeri 1 Sigli

Teacher professional development activities that have been well planned, detailed and systematic should be able to be carried out well, but in the implementation there are some activities that are not carried out in accordance with the plan. The existence of problems in the implementation of teacher professionalism development activities at SMA Negeri 1 Sigli can be caused by internal and external factors. Internal factors are constraints originating from the teacher itself, constraints in the form of health, location of residence, age and the ability of individual teachers. The ability to use information technology that is not comprehensive for all teachers in SMA Negeri 1 Sigli is an obstacle in the implementation of various types of teacher professional development activities. Currently the ability of information technology is the basic thing in all activities, there are no activities without the use of media technology. The average age of teachers in SMA Negeri 1 Sigli who are over 40 years is an obstacle in the implementation of activities, there are some teachers who are unable to carry out self-development activities in the form of education and training because of health factors, in the deliberation activities of subject teachers there are also many obstacles in the form of distance between the location of the activity which was far from home resulted in some participants not participating in the activity.

External factors in the form of financing in self-development in the form of further education that requires large costs without any help from the government for teachers in continuing their education. The lack of information and outreach to teachers in terms of government assistance to continue education resulted in teachers in state high schools being unable to continue their education. The implementation of functional education and training activities also encountered several obstacles for schools. Activities carried out in a very long time allow the absence of a substitute teacher in teaching and learning activities in schools. The schedule of teacher training activities organized by the department is usually the same for all teachers in a particular field of study, this has resulted in many disrupted student learning activities. However, sometimes the school only gives a few teachers to minimize the 
occurrence of vacancies in student learning activities.

There are several factors that become potential obstacles to the development of teacher potential, among others; internal factors and external factors: a) Internal factors: the lack of motivation of teachers to become teachers. Teacher administrative tasks that are considered burdensome. Lack of use of the time in school to exchange experiences with teacher colleagues about experiences good learning process. Lack of teacher interest to innovate. Qualifications or educational background that is not appropriate to the field of work. (b) External factors: Acompensation system that is not based on achievement and competence; Lack of educational facilities that support the teaching and learning process; Lack of opportunities for continuing professional development .

\section{CONCLUSION}

Based on the presentation of the result of the research and discussion, it can be concluded several things from research on the development of professionalism in SMA Negeri 1 Sigli as follows: Planning for strengthening professionalism of teachers in SMA Negeri 1 Sigli is very good, systematic and detailed. Planning is carried out by the school that is the principal as the leader and the teacher concerned. Planning is carried out every year to improve teacher understanding and professionalism. In addition, professional development planning is also carried out by the education office with various types of technical guidance or education and training activities. Teacher development planning is expected to be sustainable and carried out as needed, and the principal can coordinate with relevant agencies to carry out more systematic long-term planning for the following years.

The implementation of the teacher professionalism development program in SMA Negeri 1 Sigli has been running optimally. The teacher professionalism development activities at Sigli 1 Public High School are in accordance with sustainable professional development. Selfdevelopment activities have been carried out well both in the form of functional training and collective activities, in terms of scientific writing is also very good, although not all teachers do it in one academic year, but in innovative work activities only a few teachers who do it by working together in a group of subject teachers. In the case of ongoing professional development effective supervision should be given and given awards or penalties for teachers who do not carry out professional development. With this intense supervision it is hoped that activities can be carried out according to plan.

The implementation of professionalism development activities at SMA Negeri 1 Sigli is constrained by several things, namely, the obstacles that arise from the individual teachers such as the lack of understanding of some teachers in the use of ICT, the location of professional development activities are very far from the location of residence, as well as the age and health. Externally, there is a lack of financial information on self-development in the form of further education and a schedule for the implementation of education and training activities which can simultaneously interfere with school activities, so that the teacher cannot attend these activities. In this case it is expected that those who regulate teacher development activities can evaluate the activities that have been carried out and facilitate the obstacles faced by teachers in their professional development.

\section{REFERENCES}

Bakar, R. (2018). The influence of professional teachers on Padang vocational school students' achievement. Kasetsart Journal of Social Sciences, 39(1), 67-72.

Blanchard, A. G., Blanchard, G., Gowreea, Y., \&DePryck, K. (2019, June). ICT 
484 | Jurnal Pendidikan Progresif, Vol. 10, No. 3, pp. 478-484, November 2020

competences of teachers in Higher Education in developing countries. Challenges for quality education for professional development based on the DigCompEdu framework. In EdMedia+ Innovate Learning (pp. 547-552). Association for the Advancement of Computing in Education (AACE).

Darmuki, A. (2018). The Development and Evaluation of Speaking Learning Model by Cooperative Approach. International Journal of Instruction, 11(2), 115-128.

DeNisi, A. S., \& Murphy, K. R. (2017). Performance appraisal and performance management: 100 years of progress?.Journal of Applied Psychology, 102(3), 421.

Gutiérrez, G., Canul-Reich, J., Zezzatti, A. O., Margain, L., \& Ponce, J. (2018). Mining: Students comments about teacher performance assessment using machine learning algorithms. International Journal of Combinatorial Optimization Problems and Informatics, 9(3), 26-40.

Hochstetler, S., \&Orzulak, M. J. M. (2019). Writing Problems and Promises in Standardized Teacher Performance Assessment. Possibilities, Challenges, and Changes in English Teacher Education Today: Exploring Identity and Professionalization, 57.

Hutt, E. L., Gottlieb, J., \& Cohen, J. J. (2018). Diffusion in a vacuum: edTPA, legitimacy, and the rhetoric of teacher professionalization. Teaching and Teacher Education, 69, 52-61.

Kelly,A. F., Bell, J., Dicker, R., Garcia, M., Kelly, E., Streich, R., \&Mulrooney, H. (2019). Active learning across disciplines: opportunities to develop employability skills and leadership potential in undergraduate students. A student and staff perspective. New Directions in the Teaching of
Physical Sciences, 14(1).

LaRochelle, R., Nickerson, S. D., Lamb, L. C., Hawthorne, C., Philipp, R. A., \& Ross, D. L. (2019). Secondary Practising Teachers' Professional Noticing of Students' Thinking about Pattern Generalisation. Mathematics Teacher Education and Development, 21(1), 427.

Liu, Y., \&Xu, F. (2019, January). Research on Strengthening the Professional Ethics of College Teachers. In 2018 International Workshop on Education Reform and Social Sciences (ERSS 2018). Atlantis Press. 